\title{
Estimation of genetic diversity among sugarcane (Saccharum species com- plex) clones
}

\author{
Rashmi Bisht, A. S. Jeena*, Deepak Koujalagi, S. P. Singh and K. A. Khan
}

Department of Genetics and Plant Breeding, G. B. Pant University of Agriculture and Technology, Pantnagar (Uttarakhand), INDIA

*Corresponding Author: dr.asjeena@gmail.com

Received: November 11, 2016; Revised received: March 15, 2017; Accepted: July 25, 2017

\begin{abstract}
The experimental materials consisted of 36 sugarcane clones including two checks (Co Pant 97222 and Co Pant 3220). Analysis of variance revealed significant differences among all the clones for all the traits under study namely no. of millable canes, cane height, single cane weight, juice sucrose percent, purity percent, cane yield and CCS yield except cane thickness, juice brix and juice extraction percent. The divergence studies through Mahalanobis $D^{2}$ statistics grouped the 36 genotypes into eleven clusters. The maximum numbers of genotypes (21) were grouped in clusterl and the lowest(1)in cluster VI,VII, VIII,IX,X and XI. Members of cluster VII and XI (46.48) were found to be genetically most diverse on the basis of their inter cluster difference as opposite to clusters I and II (10.77) which are closely related. Cane height contributed maximum (15.397\%) towards genetic divergence followed by Single cane weight $(14.762 \%)$ and no. of millable cane $(13.016 \%)$. These characters were considered to be most important for the genetic diversity. Lowest contribution was made by juice purity percent $(4.286 \%)$ followed by Cane thickness(7.301\%), Juice extraction percent (7.619\%). Genetic diversity is important for sustainable production since greater losses of characteristics in any population limits its chances of survival. Little to no genetic diversity makes crops extremely susceptible to widespread biotic and abiotic stresses. Genetic diversity can be assessed by Mahalanobis $D^{2}$ statistic, which is a morphometric method and a powerful tool in quantifying the degree of divergence at genotypic level.
\end{abstract}

Keywords: Characterization, Clusters, Diversity, $D^{2}$ statistics

\section{INTRODUCTION}

Sugarcane (Saccharum spp. complex) is an important industrial crop of tropical and subtropical regions of the world and is cultivated in about 100 countries around the globe for its high concentrations of sugar and recently for the production of ethanol as a source of bio-fuel (Andreoli and De Souza 2007). Sugarcane has recently highlighted as a source of sustainable energy for the cogeneration of electricity and cellulosic ethanol from bagasse (Hofsetz and Silva, 2012). The by- products of the sugar industry are bagasse, molasses, filter-cake, wax etc. (Kang et al., 2013). The percentage of sucrose varies from $12-18 \%$ depending of the variety of cane, its maturity, condition of soil, climate and agricultural practices followed by the growers (Singh and Singh 2002). The genus Saccharum, established by Linnaeus in 1793, belongs to family Poacae, subfamily Panicoideae, tribe Andropogoneae, subtribe Saccharineae and genus Saccharum (Watson et al., 1985). There are five species of this genus. Three among these are cultivated species namely $S$. officinarum originated in New Guinea / Indo-BurmaChina border. $S$. barberi originated from North India. $S$. sinense originated from China. The two wild species are $S$ spontaneum originated from India and and $S$. robustum originated from New Guinea.Considerable difficulties have been faced in the improvement of sugarcane through hybridization due to narrow base of variation available. In sugarcane crop improvement is impeded by its narrow gene pool, complex genome, and poor fertility, caused by genetic recombination as well as long breeding selection cycle. The success of sugarcane breeding program therefore lies in the proper choice of rich and genetically diverse parents. The genetically diverse parents may be selected on the basis of diverse geographical distribution of the genotypes, information on agronomic characters (Melchinger, 1998). Normally in sugarcane breeding programs, the parental lines are selected on the basis of agronomic characters and pedigree records, bi-parental crosses and polycrosses between elite genotypes are used. The lack of genealogy data and the improper identification of some genotypes may impair estimation of the genetic diversity among sugarcane accessions. In addition, the continuous selection for the same traits such as sucrose content in breeding programs has lead to a reduction in genetic diversity, limiting further success in sugarcane breeding (Creste et al., 2010). 
Genetic diversity is important for sustainable production in crop species since greater losses of characteristics in any population may limit its chances of survival and requires greater human efforts for sucessful production (Trethowan and Kazi, 2008). Genetic diversity that arise due to geographical isolation or due to genetic barriers to cross ability or due to different patterns of evolution and can be measured following $\mathrm{D}^{2}$ statistics that measure group distance based on multiple characters (Mahalanobis, 1936) and it has been one of the important technique to assess genetic divergence on the basis of multiple traits. Mahalanobis $\mathrm{D}^{2}$ statistic is a morphometric method and a powerful tool in quantifying the degree of divergence at genotypic level. Several studies on degree of divergence based on phenotypic observations in different crops shown that accessions from the same geographical area may differ genotypically as well as phenotypically and also in Rao adaptability.Rao (1952) suggested the application of Mahalanobis $\mathrm{D}^{2}$ statistic for the assessment of genetic diversity in plant breeding. Keeping in view the above facts, present investigation was carried out based on with the following objective to estimate extent of genetic diversity among early generation clones of sugarcane based on morphological characterization.

\section{MATERIALS AND METHODS}

The present investigation was conducted at Sugarcane Breeding Block, Norman E. Borlaug Crop Research Centre, G.B. Pant University of Agriculture and Technology Pantnagar with early generation clones of Sugarcane. The clones were selected from $\mathrm{C}_{2}$ generation and planted as $\mathrm{C}_{3}$ generation. Thirty-four early generation clones $\left(\mathrm{C}_{3}\right)$ of sugarcane along with two checks was planted in randomized block design with two replications. Each experimental plot consisted of four rows each of five meters with $75 \mathrm{~cm}$ (row to row) distances and the details about the genotypes are presented in the Table.1.Ten quantitative characters were observed which included morphological as well as juice quality parameters. Observations were recorded either on plot basis or on a sample of five plants per plot. Morphological characters were recorded at different stage of development and juice and quality characters at the time of harvesting. The characters observed include: Numbers of millable canes: Canes bearing appreciable height i.e. more than $1 \mathrm{~m}$ were considered as millable canes, Cane height (m): The cane height was measured in meters with the help of a measuring tape from the ground surface to the topmost internode of cane stalk, Cane thickness (cm):Cane thickness was measured at the middle of cane with the help of vernier calliper in centimetre, Cane weight $(\mathrm{kg})$ : The weight of five randomly selected canes was recorded in kilogram and average single cane weight was calculated, Juice brix percent:Sample of five randomly selected cane stalks were crushed in a cane crusher. The juice was poured in graduated measuring cylinders of $500 \mathrm{ml}$ and brix hydrometer was suspended in this cylinder. When the brix hydrometer stopped oscillating in the cylinder, then the reading was recorded, Juice sucrose percent: the sucrose percent was estimated following the method given by Spancer and Meade (1955), the sucrose percent in juice was noted for corresponding values of the brix and pol reading, Juice purity percent: The juice purity percentage was calculated by using the formula given in equation 1.A cane crop is considered fit for harvesting if it has attained a minimum of $16 \%$ sucrose and $85 \%$ purity.Juice extraction percent: Juice extraction percentage was calculated by using formula given as equation 2. Cane yield: Cane yield in $\mathrm{kg}$ per plot was determined by multiplying the number of millable canes (NMC) with average cane weight (i.e. single cane weight) and later was converted into tonnes per hectare as per the equation 3.Commercial cane sugar (CCS) yield: The CCS yield tonnes per hectare were calculated by multiplying CCS percent (Equation 4) with cane yield per hectare as per equation 5 .

Juice purity percent $=$ (Juice sucrose/Juice Brix) $\mathrm{X}$ Juice Extractionpercent $=\frac{\text { Total } \text { juice weight obtained fromstalks }}{\text { Totalcaneweight of the canecrushed }} \times 100$ 100 ............1 ............2

Cane yield $=$ Number of Millable cane $\times$ Single cane weight

CCS percent $=[$ Sucrose $\%$ in juice $-($ Brix $\%$ in juice Sucrose $\%$ in juice) $\times 0.4] \times 0.73$

CCS yield $(\mathrm{t} / \mathrm{ha})=\mathrm{CCS}$ percent $\times$ Cane yield $(\mathrm{t} / \mathrm{ha})$

\section{Statistical analysis:}

Estimation of genetic divergence:The estimation of genetic divergence was done with the help of Mahalonobis' " $\mathrm{D}$ " " statistic (generalized distance) as suggested by Rao (1952). Its calculation involved the following steps.a. A set of uncorrelated linear combinations (Y,s) was obtained by Pivotal condensation of the common dispersion matrix formed by a set of correlated variables $(\mathrm{X}, \mathrm{s})$. The common dispersion matrix was obtained with the help of error mean squares and sum of products.b. Using the relationship between $\mathrm{Y}, \mathrm{s} \& \mathrm{X}, \mathrm{s}$ the mean values of different genotypes for different characters were transformed into mean value of a set of uncorrelated linear combinations.c. The $\mathrm{D}^{2}$ value between ' $\mathrm{i}$ ' $\&$ ' $\mathrm{j}$ 't' genotypes for $\mathrm{k}^{\text {th }}$ character was calculated as: $\mathrm{D}^{2}{ }_{\mathrm{ij}}$ $=\sum_{\mathrm{t}=1}^{\mathrm{k}}\left(\mathrm{Y}_{\mathrm{it}}-\mathrm{Y}_{\mathrm{jt}}\right)^{2}$

Group constellation: All the genotypes were grouped into clusters on the basis of $\mathrm{D}^{2}$ values, as suggested by 
Table 1. Details of the genotypes under study.

\begin{tabular}{|c|c|c|c|c|c|}
\hline S. N. & Clone number & Parentage & S. No. & Clone number & Parentage \\
\hline 1. & PC 2007-08- 5 & $\begin{array}{l}\text { CoS } 8436 \times \text { Co } \\
\text { Pant } 97222\end{array}$ & 19. & PC 2007-08- 124 & Co Pant 1216 GC \\
\hline 2. & PC 2007-08- 21 & Co $98010 \mathrm{GC}$ & 20. & PC 2007-08- 126 & Co Pant $1216 \mathrm{GC}$ \\
\hline 3. & PC 2007-08- 33 & Bo $91 \mathrm{GC}$ & 21. & PC 2007-08- 128 & Co Pant 1216 GC \\
\hline 4. & PC 2007-08- 44 & $\begin{array}{l}\text { CoSe } 92423 x \\
\text { CoS } 8436\end{array}$ & 22. & PC 2007-08- 253 & Co Pant 1216 self \\
\hline 5. & PC 2007-08- 51 & CoLk 8002 GC & 23. & PC 2007-08- 159 & $\begin{array}{l}\text { CoS } 8436 \times \text { Co } \\
89003\end{array}$ \\
\hline 6. & PC 2007-08- 68 & CoS 97264 GC & 24. & PC 2007-08- 165 & $\begin{array}{l}\text { CoS } 8436 \times \text { Co } \\
89003\end{array}$ \\
\hline 7. & PC 2007-08- 75 & CoS 97264 GC & 25. & PC 2007-08- 182 & Co 239 GC \\
\hline 8. & PC 2007-08- 78 & $\mathrm{CoH} 114 \mathrm{GC}$ & 26. & PC 2007-08- 192 & $\begin{array}{l}\text { Co Pant } 97213 \times \\
\text { Co } 62198\end{array}$ \\
\hline 9. & PC 2007-08- 87 & $\mathrm{CoH} 114 \mathrm{GC}$ & 27. & PC 2007-08- 214 & $\begin{array}{l}\text { IHS } 100 x \\
\text { Co86002 }\end{array}$ \\
\hline 10. & PC 2007-08- 90 & $\mathrm{CoH} 114 \mathrm{GC}$ & 28. & PC 2007-08- 223 & $\mathrm{CoS} 8432 \mathrm{GC}$ \\
\hline 11. & PC 2007-08- 92 & $\mathrm{CoH} 114 \mathrm{GC}$ & 29. & PC 2007-08- 253 & CoJ 77 GC \\
\hline 12. & PC 2007-08- 96 & $\mathrm{CoH} 114 \mathrm{GC}$ & 30. & PC 2007-08- 269 & $\begin{array}{l}\text { Co Pant } 99214 \\
\text { GC }\end{array}$ \\
\hline 13. & PC 2007-08- 100 & $\mathrm{CoH} 114 \mathrm{GC}$ & 31. & PC 2007-08- 294 & Co Pant 90223 \\
\hline 14. & PC 2007-08- 111 & $\operatorname{CoS} 8436$ PC & 32. & PC 2007-08- 297 & CoJ 99192 GC \\
\hline 15. & PC 2007-08- 114 & CoS 8436 PC & 33. & PC 2007-08- 264 & CoLk 8102 GC \\
\hline 16. & PC $2007-08-115$ & CoS 8436 PC & 34. & PC 2007-08- 295 & CoJ 99192 GC \\
\hline 17. & PC 2007-08- 117 & Co Pant 1216 GC & 35. & Co Pant 3220 & Standard variety \\
\hline 18. & PC 2007-08- 120 & Co Pant 1216 GC & 36. & Co Pant 97222 & Standard variety \\
\hline
\end{tabular}

Table 2. Analysis of variance for various characters in sugarcane.

\begin{tabular}{|c|c|c|c|c|c|c|c|c|c|c|c|}
\hline \multirow[b]{2}{*}{$\begin{array}{l}\text { Source of } \\
\text { variation }\end{array}$} & \multirow[b]{2}{*}{ d.f. } & \multicolumn{9}{|c|}{ MEAN SQUARES } & \multirow[b]{2}{*}{$\begin{array}{l}\text { CCS } \\
\text { Yield } \\
(\mathbf{t} / \mathbf{h})\end{array}$} \\
\hline & & $\begin{array}{l}\text { No. of } \\
\text { millable } \\
\text { canes }\end{array}$ & $\begin{array}{l}\text { Cane } \\
\text { height } \\
\text { (m) }\end{array}$ & $\begin{array}{l}\text { Cane } \\
\text { thick- } \\
\text { ness } \\
(\mathrm{cm})\end{array}$ & $\begin{array}{l}\text { Single } \\
\text { cane } \\
\text { weight } \\
(\mathrm{kg})\end{array}$ & $\begin{array}{l}\text { Juice } \\
\text { brix } \\
\%\end{array}$ & $\begin{array}{l}\text { Juice } \\
\text { su- } \\
\text { crose }\end{array}$ & $\begin{array}{l}\text { Juice } \\
\text { purity } \\
\%\end{array}$ & $\begin{array}{l}\text { Juice } \\
\%\end{array}$ & $\begin{array}{l}\text { Cane } \\
\text { yield } \\
(t / h)\end{array}$ & \\
\hline Replications & 1 & 8.6 & 0.03 & 0.002 & 0.000 & 2.1 & 0.8 & 9.1 & 182.2 & 28.4 & 1.5 \\
\hline Treatments & 35 & $933.8 * *$ & $0.1 * *$ & $0.053^{\mathrm{ns}}$ & $0.055 * *$ & 2.2 & $5.1 * *$ & $82.8^{* *}$ & 16.5 & $1850.7 * *$ & $27.1 * *$ \\
\hline Error & 35 & 57.1 & 0.02 & 0.04 & 0.004 & 1.3 & 0.49 & 30.8 & 11.6 & 133.7 & 2.9 \\
\hline SE (Mean) & & 5.3 & 0.10 & 0.15 & 0.046 & 0.8 & 0.49 & 3.9 & 2.415 & 8.1 & 1.2 \\
\hline CV\% & & 7.2 & 6.1 & 8.7 & 4.76 & 6.4 & 4.3 & 6.1 & 6.603 & 8.0 & 10.7 \\
\hline $\mathrm{CD}$ at $5 \%$ & & 15.3 & 0.2 & 0.4 & 0.13 & 2.3 & 1.4 & 11.2 & 6.933 & 23.4 & 3.5 \\
\hline
\end{tabular}

Table 3. Clustering patternsof 36 genotypes on the basis of $D^{2}$ values.

\begin{tabular}{lll}
\hline $\begin{array}{l}\text { Cluster } \\
\text { No. }\end{array}$ & \multicolumn{1}{c}{ Genotypes included } & $\begin{array}{l}\text { No. of } \\
\text { Genotypes }\end{array}$ \\
\hline I & PC 2007-08-5, PC 2007-08-33, PC 2007-08-44PC 2007-08-68, PC 2007-08-75, PC 2007-08-92, & 21 \\
& PC 2007-08-96, PC 2007-08-100, PC 2007-08-115, PC 2007-08-120, PC 2007-08-124, PC 2007 \\
& -08-128, PC 2007-08-159, PC 2007-08-165,PC 2007-08-182, PC 2007-08-192, PC 2007-08-214, \\
& PC 2007-08-253, PC 2007-08- 264, PC 2007-08-295, Co Pant 3220 & 3 \\
II & PC 2007-08- 90,PC 2007-08- 269,PC 2007-08- 294 & 2 \\
III & PC 2007-08- 111,PC 2007-08- 114 & 2 \\
IV & PC 2007-08- 223, Co Pant 97222 & 2 \\
V & PC 2007-08- 51, PC 2007-08- 78 & 1 \\
VI & PC 2007-08-21 & 1 \\
VII & PC 2007-08- 87 & 1 \\
VIII & PC 2007-08- 117 & 1 \\
IX & PC 2007-08- 126 & 1 \\
X & PC 2007-08- 253 & 1 \\
XI & PC 2007-08- 297 & 1 \\
\hline
\end{tabular}

Tocher. In the said method, two genotypes belonging to the same cluster should at least, on the average, show a smaller $\mathrm{D}^{2}$ value than those belonging to two different clusters.
Intra- and intercluster distances: To measure intracluster $\mathrm{D}^{2}$ values, the following formula was used:Intracluster $\mathrm{D}^{2}=\sum \mathrm{D}_{\mathrm{i}}^{2} / \mathrm{n}, \mathrm{n}=\mathrm{P}(\mathrm{P}-1) / 2$ Where, $\sum \mathrm{D}_{\mathrm{i}}{ }^{2}=$ is the sum of $\mathrm{D}^{2}$ values between all possible 
Table 4. Average inter and intra-cluster (diagonal) $\mathrm{D}^{2}$ values.

\begin{tabular}{|c|c|c|c|c|c|c|c|c|c|c|c|}
\hline Clusters & I & II & III & IV & V & VI & VII & VIII & IX & $\mathbf{X}$ & XI \\
\hline I & 6.90 & 10.77 & 12.16 & 13.69 & 14.43 & 15.33 & 26.77 & 15.01 & 18.58 & 21.97 & 28.00 \\
\hline II & & 9.83 & 21.08 & 15.66 & 18.49 & 15.87 & 33.18 & 21.39 & 25.51 & 24.42 & 33.31 \\
\hline III & & & 2.60 & 14.14 & 17.25 & 22.85 & 38.67 & 25.02 & 30.80 & 24.00 & 37.14 \\
\hline IV & & & & 7.32 & 23.11 & 16.39 & 31.49 & 19.06 & 26.82 & 28.51 & 36.80 \\
\hline V & & & & & 11.55 & 28.23 & 26.90 & 17.12 & 25.00 & 33.65 & 36.29 \\
\hline VI & & & & & & 0.00 & 27.58 & 29.72 & 35.14 & 31.88 & 34.42 \\
\hline VII & & & & & & & 0.00 & 17.36 & 42.91 & 34.97 & 46.48 \\
\hline VIII & & & & & & & & 0.00 & 36.07 & 39.75 & 34.77 \\
\hline IX & & & & & & & & & 0.00 & 28.69 & 42.35 \\
\hline$X$ & & & & & & & & & & 0.00 & 36.01 \\
\hline XI & & & & & & & & & & & 0.00 \\
\hline
\end{tabular}

Table 5. Contribution of different characters towards divergence in sugarcane clones.

\begin{tabular}{lll}
\hline S. N. & Character & Contribution percent \\
\hline 1 & No. of millable canes & 13.016 \\
2 & Cane height $(\mathrm{m})$ & 15.397 \\
3 & Cane thickness $(\mathrm{cm})$ & 7.301 \\
4 & Single cane weight $(\mathrm{kg})$ & 14.762 \\
5 & Juice brix percent & 8.889 \\
6 & Juice sucrose percent & 9.682 \\
7 & Juice purity percent & 4.286 \\
8 & Juice extraction percent & 7.619 \\
9 & Cane yield $(\mathrm{t} / \mathrm{h})$ & 9.206 \\
10 & CCS yield $(\mathrm{t} / \mathrm{h})$ & 9.841 \\
\hline
\end{tabular}

combinations (n) of the populations (P) included in a cluster.n $=$ all possible combinations among the populations in a cluster.P $=$ number of populations included in a cluster. The square root of intercluster $\mathrm{D}^{2}$ values $\left(d=\sqrt{ } D^{2}\right)$ was used to represent intra-cluster distance of a cluster.

Contribution of different character towards Divergence: The relative contribution of different characters to the total $\mathrm{D}^{2}$ between each pair of genotypes was given a score of 1 to $\mathrm{P}$ ( $\mathrm{P}$ being the number of characters) based on the magnitude of $\mathrm{D}^{2}$ values due to each character. A rank of 1 represents the highest contribution and $\mathrm{P}$ the lowest of character ' $\mathrm{X}$ '. Contribution of each character was calculated using the following formula(Equation 6):

Equation No 6: Percent contribution of a character $=$

$$
\frac{N(X)}{n(n-1) / 2} \times 100
$$

Where, $\mathrm{N}(\mathrm{X})=$ Number of genotypic combinations which were ranked first for the character ' $X$ ', out of the total genotypic combinations of $n(n-1) / 2$ and $n=$ Number of genotypes.

\section{RESULTS AND DISCUSSION}

Analysis of variance: Analysis of variances was carried out for all the 10 characters comprising yield \& quality characters under randomised block design and the results are presented in the Table. 2 . It provides that there were significant differences among clones for all the characters except for Cane thickness, juice brix and juice extraction percent. The variances (mean square) for no. of millable canes (933.896), cane height (0.113), single cane weight $(0.055)$, juice sucrose percent (5.198), purity percent (82.820), Cane yield (1850.721) and CCS yield (27.162) were found to be highly significant. This indicates sufficient genetic variability among the clones undertaken for study. Coefficient of variability was in the range of 4.32 to 10.73 , which indicates the consistency of the experimental conditions. Although the results evidenced the existence of genetic variability in the sugarcane clones tested, this variability should be further increased by divergent crosses to raise the probability of finding superior clones. Crosses of divergent genotypes raise the heterotic effect Silva et al. (2005) and avoid future problems with inbreeding depression Ferreira et al. (2005), which improves the chances to select superior clones in the segregating populations derived from these divergent crosses (Sanghera et al., 2015).

Genetic divergence analysis based on morphological traits: The genetic divergence present among the clones was estimated by Mahalanobis $\mathrm{D}^{2}$ statistic as described by Rao (1952). Based on $\mathrm{D}^{2}$ values, the constellation of genotypes into clusters was done following Tocher's method Rao (1952). All the thirty six genotypes of sugarcane could be grouped into eleven clusters. The clustering pattern of these genotypes is given in Table.3. The cluster I comprised of twenty one genotypes while the cluster II comprised of three genotypes, Cluster III, cluster IV and cluster $\mathrm{V}$ consisted of two genotypes each. Rest of the clusters viz., VI, VII, VIII, IX, X and XI had one genotype each.On average most of the clones $(58.3 \%)$ remained in group 1 , while the other groups comprised only 1 to 3 clones. The high percentage of plants in only one group indicates the low divergence found. It means that the degree of divergence among the material tested with respect to traits under study was not high .This may have been due, in part, to the narrow genetic basis of these clones or the selection presure put on these clones in previous clonal selection cycles. The selection in sugarcane improvement programs is directed to traits of agronomic interest 
and, in advanced stages, a great number of genotypes has been discarded. So, clones of the C3 stage are phenotypically much more similar genotypes, due to previous selection in early stages that alter the genotypic mean in the desirable direction. These findings were confirmatory with the findings of Silva et al. (2005) where they found 105 clones out of 129 sugarcane clones were clustered in a single group. Atkin et al. (2009) have also documented the impact of depth of pedigree and inclusion of historical data on the estimation of additive variance and breeding values in a sugarcane breeding program. Singh and Bains (1968) also reported that characters constellation that might be associated with a particular region in nature could loose their individuality under selection and human interference.

Intra and inter-cluster divergence: Intra-cluster average $\mathrm{D}^{2}$ values ranged from 0.00 to 11.55 . It was maximum in cluster $\mathrm{V}$ (11.55) with two genotypes followed by cluster II (9.83) having three genotypes, cluster IV (7.32) with two genotypes, cluster I (6.90) with twenty one genotypes and cluster III (2.60) with two genotypes. Cluster VI, VII, VIII, IX, X and XI has only one genotype each, thus intra-cluster distance in these clusters was zero. The inter-cluster average $\mathrm{D}^{2}$ value was maximum between cluster VII and XI both with one genotype (46.48), indicating high genetic diversity between these two clusters. Yadav ans Singh (2010) also observed similar diversity pattern in maize inbred lines. Thus, exploitation of genotypes within these two clusters as parents for crossing could produce good segregants. This was followed by average $\mathrm{D}^{2}$-value between cluster VII and IX with one genotype each (42.91) and average $\mathrm{D}^{2}$-value between cluster IX and cluster XI with one genotype (42.35). The minimum inter-cluster average $\mathrm{D}^{2}$-value was found between cluster I and II (10.77) followed by between cluster I and III (12.16). This might indicate the close relationship and likelihood between genotypes groups within these clusters. These results might be concluded that high $\mathrm{D}^{2}$ value was due to genetic dissimilarity among genotypes and low $\mathrm{D}^{2}$ value was due to genetic similarity among genotypes. It is concluded that hybridization of genotypes from two distant clusters is likely to yield desirable recombinants. Hybridization between genetically distant genotypes for exploiting hybrid vigour was frequently suggested in other crops species also. Therefore, two important considerations for future breeding are the selection of parents from genetically distant parents and selection of particular sugarcane genotypes based on higher variability among the progenies.

Contribution of different characters towards genetic divergence: The clustering of the genotypes into different clusters and the measurement of genetic distance between them alone does not account for the analysis of diversity in the population. It is highly im- portant to ascertain how much do each component character accounts for the total divergence. The relative contribution of different characters towards the expression of genetic divergence as calculated by following the standard method as suggested by Singh and Chaudhary (1977) is presented in Table5. The study on individual contribution of characters indicated that the maximum contribution towards divergence was given by Cane height $(15.397 \%)$ followed by Single cane weight $(14.762 \%)$, No. of millable canes $(13.016 \%)$, CCS yield (9.841\%), Juice sucrose percent $(9.682 \%)$, Cane yield (9.206\%) and Juice brix percent $(8.889 \%)$. Chourasia et al. (2017) in barley and Nair et al. (1998) in sugarcane also reported that height contributes the maximum towards divergence. This can also be inferred from this significant value that it is useful to include this character in divergence analysis. Sajjad and Khan (2009) reported that cane weight had a major contribution to genetic divergence in sugarcane.Similarly Kang et al. (2013) also reported that cane height and cane weight contributes significantly towards genetic divergence in sugarcane. Rao et al. (1985) and Nair et al. (1998) narrated that clump weight significantly adds to genetic diversity among sugarcane clones. This came true in the present research as it contributes $14.76 \%$ to divergence and appears next to cane height. Lowest contribution was made by juice purity percent $(4.286 \%)$ followed by Cane thickness $(7.301 \%)$, Juice extraction percent (7.619\%). Punia et al. (1983) also reported that among twelve characters purity percentage was the least contributor in genetic diversity for sugarcane. Here, the result is similar to Punia et al. (1983) as purity percentage contributes least in genetic divergence.

\section{Conclusion}

All the thirty six genotypes of sugarcane were grouped into eleven clusters based on $\mathrm{D}^{2}$ statistics. Most of the clones remained in group 1, while the other groups comprised only 1 to 3 clones. This indicates the low divergence found due, in part, to the narrow genetic basis of these clones or the selection presure put on these clones in previous clonal selection cycles.Intra cluster average $\mathrm{D}^{2}$ values ranged from 0.00 to 11.55 . It was highest in cluster $\mathrm{V}(11.55)$. Likewise, the inter-cluster average $\mathrm{D}^{2}$-value was highest between cluster VII and XI, whereas, minimum average inter-cluster $\mathrm{D}^{2}$ value was observed between cluster I and II followed by between cluster I and III. It indicated that the genotypes of these clusters are very close to each other. These results suggest that the sugarcane genotypes taken under investigation having a most diverse range of cane height followed by variable single cane weight, no. of millable canes contribute most towards diversity. The clustering and genetic distance also gives an idea for developing the diverse genetic pool for successful breeding 
programme. Higher the $\mathrm{D}^{2}$ value, more diverse the genotypes are and these identified genotypes can be used as parents for comprehensive hybridisation programme.

\section{REFERENCES}

Andreoli, C. and Souza, S.P. (2007). Cane sugar: The best alternative to energy conversion. Revista Economia \& Energia, 59: 27-33.

Atkin, F.C., Dieters, M.J., and Stringer, J.K. (2009). Impact of depth of pedigree and inclusion of historical data on the estimation of additive variance and breeding values in a sugarcane breeding program. Theoretical and $\mathrm{Ap}$ plied Genetics, 119: 555-565.

Chourasia, K.N., Koujalagi, D., and Bisen, P. (2017).Diversity analysis among genotypes of barley (hordeum vulgare $l$ ) based on morphological parameters. G.J.B.B., 6(1): 149-152.

Creste, S., Pinto, L.R., Xavie, M.A., Landell, M.G.A. (2010). Sugarcane Breeding Method and Genetic Mapping, In: Sugar Cane Bioethanol: R\&D for productivity and sustainability, L.A.B. Cortez (Ed.): 353-357.

Ferreira, F.M., Barbosa, M.H.P., Castro, R.D., Paternelli, L.A., and Cruz, C.D. (2005). Effects of inbreeding on the selection of sugar cane clones. Crop Breeding and Applied Biotechnology, 5: 174-182.

Sanghera, G.S., Kumar, R., Tyagi, V., Thind, K.S., and Sharma, B. (2015). Genetic divergence among elite sugarcane clones (saccharum officinarum 1.) Based on cane yield and quality traits from northern India. Journal of experimental biology and agricultural sciences, 3(2)

Hofsetz, K., and Silva, M.A. (2012). Brazilian sugarcane bagasse: Energy and non-energy consumption. Biomass Bioenerg. 46: 564-573.

Kang, S.A., Noor, M., Khan, F.A. and Saeed, F. (2013). Divergence analysis and association of some economical characters of sugarcane (Saccharum officinarum L.). Journal of Plant Breeding and Genetics. 1: 01-06.

Mahalanobis, P.C. (1936). On the generalized distance in statistics. Proc. Nat. Ins. Sci. India, 12:49-55.

Melchinger, A.E., Kuntze, L., Gumber, R.K., Lubberstedt, T., and Fuchs, E. (1998). Genetic basis of resistance to Sugarcane mosaic virus in European Maize germplasm.
Theor. Appl. Genet. 96: 1151-1161

Nair, N.V., Balakrishnan, R., and Sreenivasan, T.V. (1998). Variability for quantitative traits in exotic hybrid germplasm of sugarcane. Gen. Res. and Crop Evolution, 45(5): 459-463.

Punia, M.S., Chaudhary, B.S., and Hooda, R.S. (1983). Genetic divergence in sugarcane. J. Agric. Sci. 53(6): 434-436.

Rao, C.P., Rao, P.N., and Reddy, J.R. (1985). Genetic divergence analysis in sugarcane. Genetica Agraria. 39 (3): $237-247$

Rao, C.R. (1952). Advance statistical methods in biometrical research. Ed. II. New York. John Willey and Sons.

Sajjad, M., and Khan, F.A. (2009). Genetic diversity among sugarcane cultivars in Pak. American-Eurasian J. Agric. \& Environ. Sci., 6 (6): 730-736.

Silva, C. M., Gonçalves-Vidigal, M.C., Filho, P.S.V., Scapim, C.A., Daros, E., and Silvério, L. (2005). Genetic diversity among sugarcane clones (Saccharum spp.). Acta Sci. Agron.v. 27, n. 2, p. 315-319.

Singh, P. and Singh, V.P. (2002). Genetic divergence in sugarcane germplasm. Indian Journal of Agricultural Sciences 72: 252-253.

Singh, R. K., and Chaudhary, B. D. (1977). Biometrical methods in quantitative genetic analysis. Kalyani Publishers, New Delhi. 318 p.

Singh, R.B., and Bains, S.S. (1968). Genetic divergence for ginning outtern and its component in upland cotton (Gossypium hirsutum L.) varieties obtained from different geographical locations. Indian. J. Gene. Plant. Breeding, 26: 262-268.

Spancer, G.L., and Meade, G.P. (1955). Cane Sugar Hand Book. John Willey and Sons, New York: pp. 359.

Trethowan, R.M., and Kazi, A.M. (2008). Novel germplasm resources for improving environmental stress tolerance of hexaploid wheat. Crop Science, 48:1255-1265

Watson, L., Clifford, H.T., and Dalwitz, M.J. (1985). The classification of Poaceae: Subfamilies and super tribes. Aust. J. Bot. 33: 433-484.

Yadav, V.K., and Singh, I.S., (2010). Comparative evaluation of maize inbred lines (Zea mays L.) according to DUS testing using morphological, physiological and molecular markers. Agricultural Sciences, 1: 131-142. 